\title{
Nipah Virus: A Review
}

\author{
Monika $^{1 *}$, Priyanka ${ }^{1}$, Shashikala ${ }^{2}$ and Leela Wati ${ }^{1}$ \\ ${ }^{1}$ Department of Microbiology, CCS Haryana Agriculture University, Hisar-125004, India \\ ${ }^{2}$ Department of Bio and Nano Technology, Guru Jambheshwar University of Science \& \\ Technology, Hisar-125004, India \\ *Corresponding author
}

\section{A B S T R A C T}

\begin{tabular}{|l|}
\hline Ke y w o r d s \\
Nipah V virus, \\
Paramyxovirinae, \\
Pteropus, Symptoms, \\
Transmission
\end{tabular}

\section{Introduction}

Throughout the history of the world humans have been plagued by diseases of various types and origins. Zoonotic diseases, or diseases which have the capability to jump species, animals to humans or vice versa, have been particularly troublesome and deadly. Zoonotic diseases are unique in that they are mainly caused by pathogens such as fungi, bacteria, parasites, or viruses. These pathogens typically survive in a reservoir host, which have immunity to the pathogen. The list of possible reservoir hosts capable of transmitting disease to humans is expansive; however the most common are apes, insects, rodents, and bats (Chua et al., 2002). The diseases are then passed to humans who come in contact with an infected animal through bites or scratches, an infected animal's environment, or animal secretions such as saliva, feces, or mucus. Often these diseases have a higher virulence because of the lack of any immunity within the human population and the ease of transmission. Some more infamous zoonotic diseases are West Nile, Rabies, Ebola, and Dengue fever. As of recent, more and more zoonotic diseases are emerging because of an increase in human and wildlife interaction. An increase in farming and or deforestation has resulted in humans and wildlife into the same habitat. A prime example of this is the emergence of the Nipah virus (NiV) (Anno et al., 1999). Nipah Virus 
Infection (NiV) is an emerging infectious disease of public health importance in the South-East Asia Region. The virus is named after the Malaysian village where it was first discovered. This virus along with Hendra virus comprises a new genus designated Henipavirus in the subfamily Paramyxovirinae Fruit bats of the genus Pteropus have been identified as natural reservoirs of $\mathrm{NiV}$. A seroepidemiologic study in Malaysia implicated four fruit bat species, Pteropushypomelanus, $\quad P$. vampyrus, Cynopterusbrachyotis, Eonycterisspelaea, and an insectivorous bat, Scotophiluskuhlii (Yob et al., 2001). Nipah virus has been isolated from the brain and spinal fluid of victims in Malaysia. Infective virus has also been isolated from environmental samples of bat urine and partially-eaten fruit in Malaysia. The species-wise distribution of fruit bats in Asia is presented in Table 1. Given the distribution of the locally abundant fruit bats in South Asia, NiV outbreaks are likely to continue to occur in affected countries. The bats are migratory (Chua et al., 2000, Eaton et al., 2006).Fruit bats (order Chiroptera), specifically bats of the genus Pteropus, have been shown to be the natural reservoir for Nipah virus. About 60 species of pteropid bats, also known as flying foxes, are known to exist; they are native to Asia (including throughout China) and Australia, ranging as far west as the east coast of Africa and as far east as the Pacific Islands. The bats develop subclinical disease due to Nipah virus and are assumed to be the intermediate hosts for infections of humans.

\section{Morphology}

Nipah virus is in the newly created Henipavirus genus with the closely related Hendra virus and Cedar virus. The Henipavirus family is pleomorphic, meaning their shape is varied, and traditionally 40 to $600 \mathrm{~nm}$ in diameter. The core of a virion contains a linear ribonucleprotein (RNP) comprising of negative sense single stranded RNA. Also present in the RNP are three critically important proteins. Nucelocapsid proteins $(\mathrm{N})$ are tighly bound to the various nucleotides of the RNA strand $\mathrm{N}$ protein is the most abundant protein present and necessary for capsid structure. Phosphoproteins (P) and large polymerase proteins (L) are also bound to the RNA and aid RNA polymerase in transcribing RNA to mRNA to antigenomic RNA. The virion is enveloped by a traditional lipid bilayer but "spiked" with fusion (F) and receptor-binding glycoproteins $(\mathrm{G})$. The fusion proteins are responsible for fusing the viral membrane to the host membrane triggering the release of the contents of the virion. The receptor-binding glycoporteins are extremely specific and bind only to Ephrin B2 (EFNB2) surface proteins. Specifically, NiV has been found to alternatively bind to EFB3 as well. The EFNB2 surface proteins are highly conserved across the mammalian lineage (Wacharapluesadee et al., 2005).On the underside of the lipid bilayer matrix proteins (M) are present for structural support and regulating the budding process. Other proteins, $\mathrm{C}, \mathrm{V}$, and $\mathrm{W}$, are also present in the cytoplasm and involved in regulation of transcription and replication. In regards to the Nipah virus genome, the exact structure is not completely understood. However because of the strong homology between Hendra virus and Nipah virus, a nearly identical structure is hypothesized. The negative sense single stranded RNA is of traditional 3' to 5' orientation. All the previously mentioned proteins are encoded by the RNA in the order of 3'-N-P-M-F-G-L- 5'12. Similar to all paramyxoviruses NiV RNA replication occurs in the cyptoplasm. All but the $\mathrm{P}$ gene are monocystronic, in that they code for a single protein. The $\mathrm{P}$ gene alsoencoded for the $\mathrm{C}, \mathrm{V}$, and $\mathrm{W}$ proteins which play a role in the virulence of $\mathrm{NiV}$. Interferons are released by host cells when under attack by a pathogen 
which enables intercellular communication. The intercellular communication is necessary for the triggering of immune cells which get rid of the pathogen. $\mathrm{C}, \mathrm{V}$, and $\mathrm{W}$ proteins, encoded by the $\mathrm{P}$ gene, have anti-interferon activity in that they block the transcription of interferon signaling. The process by which $\mathrm{C}$, $\mathrm{V}$, and $\mathrm{W}$ proteins block the signaling is still unknown (Hsu et al., 2004).

Strain variation Nipah viruses have been demonstrated. Genomic variation appears to be geographically distinct, with specific differences between human isolates from the outbreaks in Malaysia, India, and Bangladesh, and from batsin Cambodia (Reynes et al., 2005; Chadha et al., 2006). Although amino acid homologies between the Malaysia strain and Bangladesh strain were greater than $92 \%$, the genome of the Bangladesh strain is 6 nucleotides longer than the Malaysian strain and demonstrated enough variation to be considered a new strain. Sequences obtained from the outbreak in India had a closer relation to the Bangladesh strain than the Malaysian strain, while the virus isolated in Cambodia demonstrated closer homology to the Malaysian strain. These observations support the finding that these viruses have natural reservoirs for evolving within distinct geographic areas

\section{History}

Nipah virus (NiV) is a member of the family Paramyxoviridae, genus Henipavirus. $\mathrm{NiV}$ was initially isolated and identified in 1999 during an outbreak of encephalitis and respiratory illness among pig farmers and people with close contact with pigs in Malaysia and Singapore. Its name originated from Sungai Nipah, a village in the Malaysian Peninsula where pig farmers became ill with encephalitis. Given the relatedness of $\mathrm{NiV}$ to Hendra virus, bat species were quickly singled out for investigation and flying foxes of the genus Pteropus were subsequently identified as the reservoir for $\mathrm{NiV}$ (Annon et al., 2004a).

In the 1999 outbreak, Nipah virus caused a relatively mild disease in pigs, but nearly 300 human cases with over 100 deaths were reported. In order to stop the outbreak, more than a million pigs were euthanized, causing tremendous trade loss for Malaysia. Since this outbreak, no subsequent cases (in neither swine nor human) have been reported in either Malaysia or Singapore.

In 2001, NiV was again identified as the causative agent in an outbreak of human disease occurring in Bangladesh. Genetic sequencing confirmed this virus as Nipah virus, but a strain different from the one identified in 1999. In the same year, another outbreak was identified retrospectively in Siliguri, India with reports of person-to-person transmission in hospital settings (nosocomial transmission). Unlike the Malaysian $\mathrm{NiV}$ outbreak, outbreaks occur almost annually in Bangladesh and have been reported several times in India (Hsu et al., 2007)

\section{Mode of transmission}

Infected bats shed virus in their excretion and secretion such as saliva, urine, semen and excreta but they are symptomless carriers. The $\mathrm{NiV}$ is highly contagious among pigs, spread by coughing. Direct contact with infected pigs was identified as the predominant mode of transmission in humans when it was first recognized in a large outbreak in Malaysia in 1999 (Goh et al., 2000). Ninety percent of the infected people in the 1998- 1999 outbreaks were pig farmers or had contact with pigs

There is strong evidence that emergence of bat-related viral infection communicable to humans and animals have been attributed to the loss of natural habitats of bats. As the 
flying fox habitat is destroyed by human activity the bats get stressed and hungry, their immune system gets weaker, their virus load goes up and a lot of virus spills out in their urine and saliva (http://scienceinpublic.com.au). Similar fluctuation of virus shedding may be associated with the stressful physiological conditions or seasons.

There were focal outbreaks of $\mathrm{NiV}$ in Bangladesh and India in 2001 during winter. Drinking of fresh date palm sap, possibly contaminated by fruit bats ( $P$. giganteus) during the winter season, may have been responsible for indirect transmission of Nipah virus to humans (Luby et al., 2006) There is circumstantial evidence of human-to-human transmission in India in 2001.

During the outbreak in Siliguri, 33 health workers and hospital visitors became ill after exposure to patients hospitalized with Nipah virus illness, suggesting nosocomial infection (Chadha et al., 2006). During the Bangladesh outbreak the virus is suggested to have been transmitted either directly or indirectly from infected bats to humans. Strong evidence indicative of human- to-human transmission of NiV was found in Bangladesh in 2004 (Gurley et al., 2007)

\section{Symptoms}

In animals, typical clinical symptoms are observed in pigs where respiratory symptoms dominate. Nipah virus disease in pigs is also known as porcine respiratory and neurologic syndrome as well as barking pig syndrome based on clinical observation. Symptoms of $\mathrm{NiV}$ infection in humans are similar to that of influenza such as fever and muscle pain. Nipah virus infection produces an encephalitic syndrome predominantly characterized by fever, headache, and neurologic signs. Fever is almost universal, followed by headache in 65-
$88 \%$ of patients (Chong et al., 2000; Goh et al., 2000). A reduced level of consciousness was seen in $55 \%$ of all infected individuals during the Malaysia outbreaks (Goh et al., 2000) and in $>90 \%$ in the Bangladesh outbreaks (Hsu et al., 2004) Vomiting and dizziness are reported as prominent clinical features, which could be secondary to neurologic dysfunction. Some neurological signs reflected brain stem abnormalities, including reduced or absent reflexes, variable reactive pupils, and doll's-eye reflexes. Other specific neurologic signs noted include myoclonus, tonic-clonic seizures, and nystagmus. The respiratory system is the second most commonly affected system in Nipah virus infection. Cough, cold-like symptoms and dyspnea were the most common respiratory symptoms reported. Respiratory symptoms and abnormal chest (Anon et al., 2004a, b)

In some cases, inflammation of the brain occurs leading to disorientation or coma. Encephalitis may present as acute or late onset. The latter may be difficult to diagnose since exposure may have taken place several months earlier. Further, those who may have recovered from an acute episode may also have a relapse. Nevertheless, magnetic resonance of the brain is helpful in differentiating. The gastrointintestinal system was much less commonly affected, with some reporting symptoms of abdominal pain, diarrhea, and constipation.

\section{Diagnosis}

Procedures for the laboratory diagnosis of NiV include serology, histopathology, PCR and virus isolation. Serum Neutralization Test, ELISA, RT-PCR are used for laboratory confirmation. Most countries in the South-East Asia Region do not have adequate facilities for diagnosing the virus or on ways of controlling it. 
Table.1 Distribution of bat species previously shown to have Nipah virus

*(WHO South East Asia)

\begin{tabular}{|l|}
\hline Species \\
\hline Pteropus; \\
\hline Hipposideros \\
larvatus \\
\hline hypomelanus \\
\hline Pteropus vampyrus \\
\hline Pteropuslylei \\
\hline Pteropus giganteus \\
\hline Scotophilus kuhlii \\
\hline Eonycteris spelaea \\
\hline Cynopterus
\end{tabular}

\section{Geographic range}

Australia; Cambodia; Indonesia; Malaysia; Maldives

Bangladesh; Cambodia; China; India; Indonesia (Bali, Jawa, Kalimantan, Sumatra); Lao People's Democratic Republic; Malaysia (Peninsular Malaysia, Sabah, Sarawak); Myanmar; Thailand

Myanmar; Papua New Guinea; Philippines; Solomon Islands; Thailand; Viet Nam

Brunei Darussalam; Cambodia; Indonesia; Malaysia; Myanmar; Philippines; Thailand; Tonga; Vanuatu

Cambodia*; Thailand\#; Viet Nam

Bangladesh; Chia; India; Maldives; Nepal; Pakistan; SriLanka

Bangladesh; India; Indonesia; Malaysia; Pakistan; Philippines; Sri Lanka

China; India (Andaman Is., Andhra Pradesh, Assam, Karnataka, Manipur, Meghalaya, Nagaland, Nicobar Is.,Sikkim, Tamil Nadu, Uttaranchal); Indonesia

Cambodia; China; India (Andhra Pradesh, Bihar, Goa,Karnataka, Maharashtra, Nagaland, Tamil Nadu); IndonesiaSulawesi, Sumatra); Lao People's Democratic Republic;Malaysia; Myanmar; Nepal; Philippines; Singapore; SriLanka; Thailand; Viet Nam

Fig.1 Schematic representation of nipah virus transmission
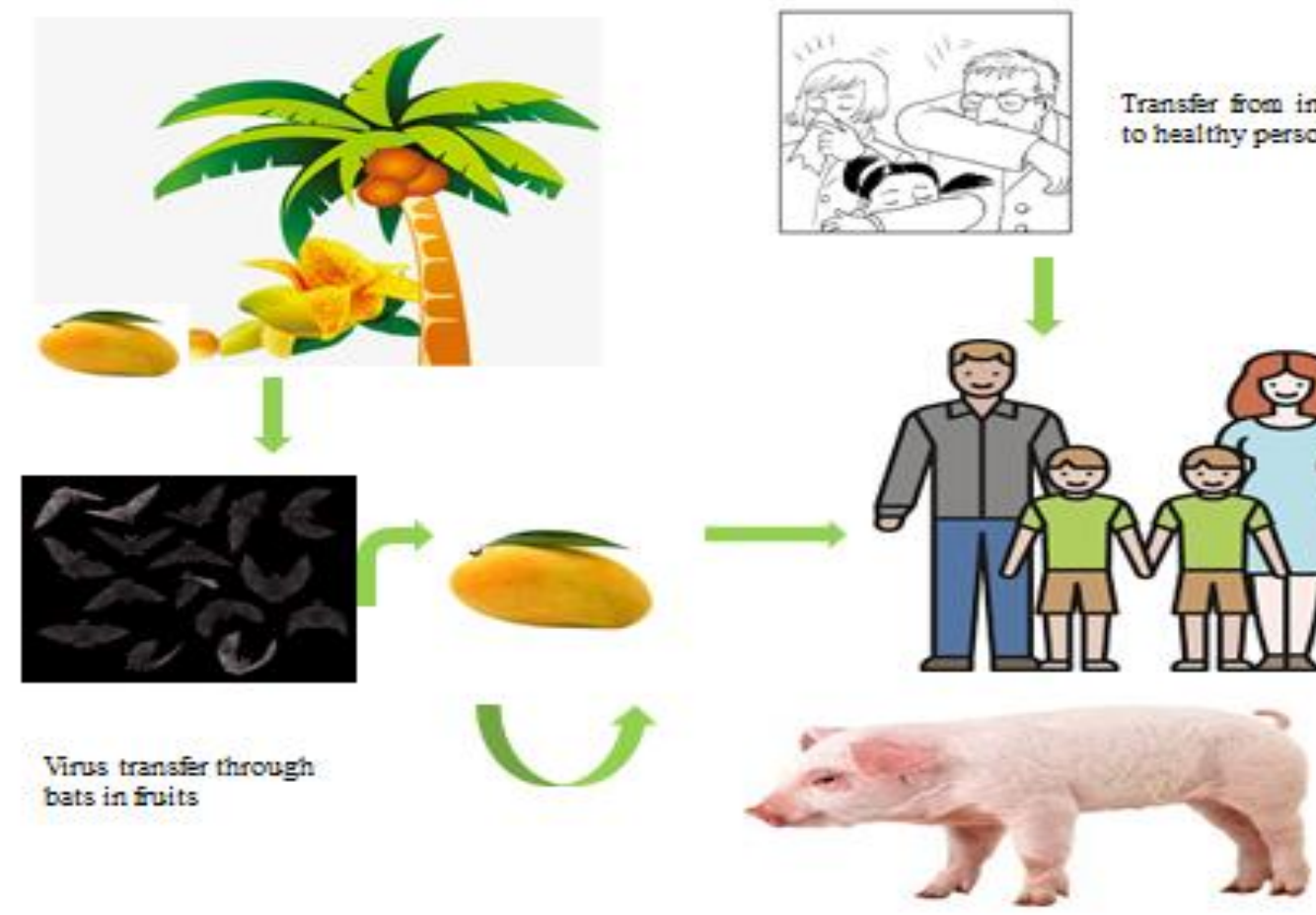
Bangladesh, India and Thailand have developed laboratory capacity for diagnostic and research purposes. Nipah virus is classified internationally as a biosecurity level (BSL) 4 agent. BSL 2 facilities are sufficient if the virus can be first inactivated during specimen collection (Daniels et al., 2001). There are a few laboratories in which the virus can be studied safely without a risk of it "escaping" and infecting more people.

\section{Treatment}

There has yet to be a standard protocol in detecting Nipah viral infections but the most common process used currently is virus isolation from tissue samples. In all species $\mathrm{NiV}$ can be detected and isolated from the kidneys, cerebrospinal fluid, and the liver. Polymerase chain reaction, enzyme-linked immunosorbent, and immunofluorescence assays are also viable detection strategies 14 (http://www.searo.who.int/entity/emerging_di seases/links/CDS_Nipah_Virus.pdf).

Currently there are no vaccines or drugs which can cure or treat a NiV infection. The primary approach is to treat the symptoms as best as possible in hope to control the infection. Creating a vaccine is currently extremely difficult because the mutation rate of RNA viruses is extremely high as is most zoonotic diseases, of which Nipah virus is both 9 Antibodies to Nipah virus have been found in 9-25\% of pteropid bats in Malaysia, Cambodia, Thailand, and Bangladesh. Neutralizing antibodies to Nipah virus were found in $P$. hypomelanus and $P$. vampyrus, the two pteropidspecies in Peninsular Malaysia; in Cambodia, antibodies were found in a third species, P. lylei; while in Thailand, antibodies were present in all three species. In Bangladesh, $P$. giagnteus bats, a more common species in that region, were found to have neutralizing antibodies to Nipah virus. Neutralizing antibodies to Nipahvirus have also been found in other frugivorous and insectivorous bat genera including Eonycteris, Cynopterus, Scotophilus, and Hipposideros, although in a lower proportion than in Pteropus spp. Till now effective treatment against nipah virus is could not discovered.

However, Ribavirin and acyclovir have been used to treat Nipah virus infectionlike nausea, headache and vomiting. In Malaysia, ribavirin was administered orally or intravenously to 140 persons with Nipah virus encephalitis and compared to a group of 54 control patients who did not receive ribavirin. A total of 45 deaths in the treated group (32\%) compared to 29 deaths in the control group (54\%) suggested a $36 \%$ reduction in mortality with ribavirin administration (Chong et al., 2001). In Singapore, acyclovir was administered to all encephalitis patients during the Nipah outbreak (Paton et al., 1999; Bellini et al., 2002). Only one fatality occurred in Singapore, but the effect that the drug had on the course of disease is unclear Treatment is mostly focused on managing fever and the neurological symptoms. Severely ill individuals need to be hospitalized and may require the use of a ventilator. However several studies have been conducted in targeting the $\mathrm{F}$ and $\mathrm{G}$ proteins which would inhibit binding of the NiV cells to any host cell.

Human-to-human transmission of $\mathrm{NiV}$ has been reported in recent outbreaks demonstrating a risk of transmission of the virus from infected patients to healthcare workers through contact with infected secretions, excretions, blood or tissues. Healthcare workers caring for patients with suspected or confirmed NiV should implement Standard Precautions when caring for patients and handling specimens from them. Vaccine is being developed. A recombinant sub-unit vaccine formulation protects against lethal Nipah virus challenge 
in cats (McEachern et al., 2008). ALVAC Canarypox vectored Nipah $F$ and $G$ vaccine appears to be a promising vaccine for swine and has potential as a vaccine for humans. The main strategy is to prevent $\mathrm{NiV}$ in humans. Establishing appropriate surveillance systems will be necessary so that $\mathrm{NiV}$ outbreaks can be detected quickly and appropriate control measures initiated (Weingartl et al., 2006).

\section{Nipah virus outbreak in India}

In January and February 2001, an outbreak of febrile illnesses occurred in the city of Siliguri, in the West Bengal region of India. Although initially reported as atypical measles, it has been retrospectively confirmed that Nipah virus was the most likely cause of the outbreak, with IgM and IgG antibodies to Nipah Virus detected in serum in 9 of 18 patients and a positive PCR in urine from 5 patients (Chadha et al., 2006). A total of 66 cases of Nipah virus encephalitis were identified with at least 43 deaths; all cases occurred in individuals over 15 years of age. No clear animal exposure was identified, but there was some evidence suggesting personto-person and nosocomial transmission Nipah virus that causes high fever, headache, and coma in extreme cases is spread by fruit bats in Kerla, India. Recently 2018, it causes 14 deaths in Kerla, 11 from Kozhikode and three from Malappuram. It was assumed that nipah virus spread from bats to fruits and from fruits to humans. However, blood and serum sample of bats collected from affected areas turned negative and health experts trying hard to pinpoint the main carriers of the virus. The government has also decided to book those ostracise family members of the affected peoples and hospital staff.

Ecologic changes, human demographics, and behavior patterns such as international travel, technology and industry, and microbial adaptation have all been factors that are thought to play a role in infectious disease emergence. It should be noted also that in Bangladesh, located at more subtropical latitude, all Nipah outbreaks occurred in the first half of the year, suggesting that perhaps climate change or bat activities affected by seasonal change may also have played a role. Until a better understanding of the causes of these newly emergent viruses is obtained, future outbreaks are likely to recur. Research is continuing to identify the factors that have led to the emergence of 2Nipah viruses in domestic animal and human populations.

\section{References}

Anno Outbreak of Hendra-like virus - Malaysia and Singapore, 1998-99.Morb.Mort. Weekly Rep., 1999, 48 (13), 265-269.

Anon. Nipah encephalitis outbreak over wide area of Western Bangladesh, 2004. Health SciBull 2004b; 2: 7-11

Anon. Nipah virus outbreak(s) in Bangladesh, January-April 2004.WklyEpidemiol Rec 2004c; 79: 168-171.

Bellini WJ, Rota P, Parashar UD. Zoonotic paramyxoviruses. In: Clinical Virology (Richman DD, Whitley RJ, Hayden FG, editors). 2nd ed. Washington, DC: ASM Press; 2002; pp. 845-855.

Chadha MS, Comer JA, Lowe L, Rota P, Rollin PE, Bellini WJ, Ksiazek T, Mishra AC. Nipah virus-associated encephalitis outbreak, Siliguri, India. Emerg Infect Dis 2006; 12:235-240.

Chadha MS, Comer JA, Lowe L, Rota PA, Rollin PE, Bellini WJ, et al., Nipah virusassociated encephalitis outbreak, Siliguri, India. Emerg Infect Dis. 2006; 12: 235-40.

Chong HT, Kamarulzaman A, Tan CT, Goh KJ, Thayaparan T, Kunjapan SR, et al., Treatment of acute Nipah encephalitis with ribavirin. Ann Neurol. 2001; 49: 810-3.

Chua KB, Bellini WJ, Rota PA, Harcourt BH, et al., Nipah virus: a recently emergent deadlyparamyxovirus. Science 2000; 288:1432-1435. 
Chua KB, Koh CL, Hooi PS, et al., (2002). «Isolation of Nipah virus from Malaysian Islandflying-foxes».Microbes Infect. 4 (2): 145-51.

http://linkinghub.elsevier.com/retrieve/pii/S 1286457901015222.

Daniels, P., Ksiazek, TG, Eaton, BT. Laboratory diagnosis of Nipah virus and Hendrainfections. Microbes Infect, 3. 2001:289-295.

Eaton BT, Broder CC, Middleton D, Wang LF, 2006. Hendra and Nipah viruses: differentand dangerous. Nat. Rev. Microbiol. 4, 23-35.

Goh KJ, Tan CT, Chew NK, Tan PS, Kamarulzaman A, Sarji SA, Wong KT, Abdullah BJ, Chua KB, Lam SK. Clinical features of Nipah virus encephalitis among pig farmers inMalaysia. N Engl $\mathrm{J}$ Med 2000; 342: 1229-1235.

Goh KJ, Tan CT, Chew NK, Tan PSK, Kamarulzaman A, Sarji SA, Wong KT, Abdullah BJJ, Chua KB, Lam SK. Clinical features of Nipah virus encephalitis among pig farmers in Malaysia. N. Engl. J. Med. 2000; 342, 1229-1235.

Gurley E, Montgomery JM, Hossain MJ, Bell M, Azad AK, Islam MR, et al., Person-toperson transmission of Nipah virus in a Bangladeshi community. Emerg Infect Dis. 2007; 13: 1031-7.

Hendra virus, ecological change and a new threat in/factsheets.htm

Hsu VP, Hossain MJ, Parashar UD, Ali MM, Ksiazek TG, Kuzmin I, Niezgoda M, Rupprecht C, Bresee J, Breiman RF. Nipah virus encephalitis reemergence, Bangladesh. Emerg Infect Dis 2004; 10: 2082-2087.

Hsu, VP, Hossain, MJ, Parashar UD et al., Nipahvirus encephalitis reemergence, Bangladesh. Emerg. Infect. Dis. 10, 2004: 2082-2087.
International Committee on Taxonomy of Viruses [database on the Internet]. [cited 2004Dec 1]. Available from http://www.ncbi.nlm.nih.gov/ICTVdb/Ictv/i ndex.htm

Luby, SP, Rahman, M, Hossain, MJ, Blum, LS, et al., Foodborne transmission of Nipahvirus, Bangladesh. Emerg Infect Dis 2006; 12:1888-1894.

McEachern JA, Bingham J, Crameri G, Green DJ, Hancock TJ, Middleton D, et al., A recombinant subunit vaccine formulation protects against lethal Nipah virus challenge in cats. Vaccine. Volume 26, Issue 31, 23 July 2008:3842-3852.

MohdNor MN, Gan CH, Ong BL. Nipah virus infection of pigs in peninsular Malaysia. Rev. Sci. Tech. Off. Int. Epiz. 2000; 19: 160-65.

Paton NI, Leo YS, Zaki SR, Auchus AP, Lee KE, Ling AE, Chew SK, Ang B, Rollin PE, Umapathi T, Sng I, Lee CC, Lim E, Ksiazek TG. Outbreak of Nipah-virus infection among abattoir workers in Singapore.Lancet 1999; 354: 1253-1256.

Reynes JM, Counor D, Ong S, Faure C, Seng V, Molia S,Walston J, Georges-Courbot MC, Deubel V, Sarthou JL. Nipah virus in Lyle's flying foxes, Cambodia. Emerg Infect Dis 2005; 11: 1042-1047

Wacharapluesadee S, Lumlertdacha B, Boongird $\mathrm{K}$, Wanghongsa S, Chanhome L, Rollin P, et al., Bat Nipah virus, Thailand. Emerg Infect Dis. 2005; 11: 1949-51

Weingartl et al., Recombinant Nipah virus vaccines protect pigs against challenge. Journal of Virology 80, 2006: 7929-38.

Yob JM, Field H, Rashdi AM, Morrissy C, van der Heide B, Rota $\mathrm{P}$, et al., Nipah virus infectionin bats (order Chiroptera) in peninsular Malaysia. Emerg Infect Dis. 2001; 7: 439-41.

\section{How to cite this article:}

Monika, Priyanka, Shashikala and Leela Wati. 2018. Nipah Virus: A Review. Int.J.Curr.Microbiol.App.Sci. 7(06): 3056-3063. doi: https://doi.org/10.20546/ijcmas.2018.706.359 